\title{
EFFECT OF BEDDING MATERIALS ON DUCK'S WELFARE AND GROWTH PERFORMANCE
}

\author{
Hesham H. Mohammed ${ }^{1 *}$, Asmaa I. Abdelaty ${ }^{1}$, Al-Sadik Y. Saleem¹, \\ Mohamed I. Youssef ${ }^{1}$, Shereen EL. Abdel-Hamid ${ }^{1}$
}

${ }^{1}$ Department of Veterinary Public Health, Faculty of Veterinary Medicine, Zagazig University, 44511, Egypt

*Corresponding author, E-mail: heshamvet_hosny@yahoo.com

\begin{abstract}
Ducks spend their entire life in contact with the litter material, thus the management strategies should focus on what is the best for ducks welfare and growth performance. Herein, the main object of the present study was assessing the effects of different litter materials on the ducks' welfare and growth performance. Four groups of ducks (24 duckling for each) were kept on four types of bedding materials, sawdust, plastic slatted floor, sand and without. The present study revealed several changes in duck's behaviors due to different bedding materials, where the most frequencies of maintenance behaviors (feeding, drinking, idling, preening) were significantly $(\mathrm{P}<0.05)$ higher in plastic slatted in comparing to other materials the highest significantly in plastic slatted litter and the lowest in non-bedding litter. Moreover, the ducks reared under sawdust floor revealed the highest frequency of foraging behavior (11.48 bouts/hour). While, feather pecking and aggression were the highest in non-bedding material (74.4, 5.51 bouts/hour, respectively). The hygienic conditions inside the non-bedding floor was the worst due to increase levels of ammonia and carbon dioxide $\left(12,0.97 \mathrm{Cm}^{3} / \mathrm{Litter}\right.$, respectively). The ducks reared in plastic slatted floor were the best in growth performance with good signs of soundness. In non-bedding floor, the environmental stress revealed in the increase the level of plasma corticosterone hormone with bad signs of soundness. This study confirms importance of bedding materials in rearing of ducks, especially under plastic slatted floor.
\end{abstract}

Key words: duck; bedding material; behavior; performance; welfare

\section{Introduction}

Poultry has an important role amongst agricultural industries in many countries. Poultry sector in Egypt is one of the major sources of animal protein supply (1). Duck production is an aspect of the poultry industry, which is very popular in many parts of the world. Ducks represent the second largest poultry production in Africa after chicken, beside pure Egyptian breeds there were some local developed strains that established for both meat and egg production (2). Duck used for meat production, which may partly compensate the increasing demand for animal protein, where duck meat is highly appreciated as it combines the characteristics of a red meat and the dietetic characteristics of poultry meat (3). From an economic standpoint, management strategies should focus on what is 
the best for poultry welfare and growth performance (4). To increase the income from ducks rearing, producers are capable of modulating the management of ducks. The well-being of poultry and stress largely influence the poultry production (5). There are many factors which can decrease the performance and increase abnormal behavior of poultry such as management and housing (6). Deep-litter floor housing is most common when raising birds used for meat production (7).In this system, better litter management is crucial for providing good litter quality and for controlling the ammonia level inside the poultry houses. Distinct mixtures of different materials have been proposed as bedding for poultry (8). Duck litter is a mixture of duck excreta, spilled feed, spontaneously fallen feathers and farm bedding material (9). Wood sawdust is the most common used bedding material, however, there were many alternative materials that may be used such as rice and wheat straw (10), soya bean straw (11) and other dry, absorbent, low-cost organic materials. Moreover, the sand is occasionally used as a bedding material (12). The ducks spend their entire life in contact with the litter material. Therefore, its quality is considered a crucial factor of poultry welfare (13), where the good litter should be characterized by good absorption property with a reasonable drying time (14), fast drought, low price and acceptable as a fertilizer. Litter quality may play an important role in the activity levels of broilers through encouraging normal behaviors that require energetic movements such as leg exercise (walking, foraging and dusting bathing) $(15,16)$. Moreover, behavior is a part of an animal's interaction with its environment. Poor litter quality is considered a welfare problem in modern poultry production. For that reason, the objective of this study was to assess the effect of different bedding material on duck welfare.

\section{Material and methods}

This experiment was done after the approval by Ethics and Animal welfare committee of the poultry Research Unit, Faculty of Veterinary Medicine, Zagazig University, Egypt (ANWD206).

\section{Experimental animals and management}

A total of ninety six one day old of Moulard duckling was collected on one batch from Faculty of Agriculture, Zagazig University. The ducks were divided randomly after one week of the brooding period into four groups (each of 24 ducklings) as according to bedding materials (17) into saw dust, plastic slatted, sand and without floor. Each group was subdivided into three replicates (each 8 birds) following identifying with wing rings and kept in brooder house in the same home pen.

Each group was kept in a pen with a floor area of $3.5 \mathrm{~m}$ length X 3 m width X $3 \mathrm{~m}$ height. Each pen had provided with one incandescent lamp of 100 watts at height $2.5 \mathrm{~m}$ above the level of ducks. During the experimental period, ducks were provided with full light for $1^{\text {st }}$ week, then decrease gradually until reach $8 \mathrm{~h} /$ day. Newly hatched duckling should have a proper brooding temperature, where it was measured by thermometer at the level of a bird's back and maintained at about $32-34{ }^{\circ} \mathrm{C}$ in $1^{\text {st }}$ week, then decreased $3-5{ }^{\circ} \mathrm{C}$ per week until it reached 19$20^{\circ} \mathrm{C}$ at 4 weeks (fully feathered ducks) (18).

Ducks were provided with ad libitum basic commercial duck's starter diet throughout the rearing phase that contained $22 \%$ crude protein until 5 weeks old. Then, they were fed on a grower diet with $18 \%$ of crude protein until the end of experiment (19).

\section{Behavioral observation}

It was conducted in the home pen to record different behavior for 5 hrs weekly from 6 am to $6 \mathrm{pm}$ by focal sample technique. Observation was done by one person standing directly in front of each group and waiting 10 minutes for acclimation of ducks (6). An observation sheet, a stop watch and photographing camera were used during the observation time for recording the behavioral pattern $(20,21)$. After observation, the total frequencies of normal and abnormal behavior were counted and calculated, as mentioned in Table (1) in all bedding materials.

\section{Other welfare indicator}

At the end of the study, the ducks were captured and measured the physical condition (22). 
The condition of eye, nostril, feather, foot and gait was scored as the welfare indicators. The other welfare score was ranged from zero to two, where zero was the best and one was the worst.

\section{Growth performance parameters}

It was recorded previously (23), where, initial body weight (IBW) of ducks was weighed at the beginning of experiment ( $2^{\text {nd }}$ weeks age) and weekly until $10^{\text {th }}$ weeks age, also feed residues and thus average feed intake (FI) were recorded weekly. Average body weight gain (ABWG) was calculated by subtracting body weight between two successive weeks. Relative growth rate (RGR) was calculated by ABWG/ (initial $\mathrm{BW}+$ final $\mathrm{BW}) * 0.5$. Furthermore, feed conversion ratio (FCR) was calculated (feed intake/weight gain) over a period of experiment.

\section{Blood sampling and cortisol level}

At the end of the experimental period, blood samples had been collected randomly from 15 ducks/group, at morning to overcome the circadian variation in hormone level (23). Blood samples were obtained from wing vein into heparinized tubes, centrifuged at $4000 \mathrm{rpm}$ for 15 min to obtain blood plasma, which stored on $-80^{\circ} \mathrm{C}$ for evaluating the cortisol level, as one of stress indicating hormones (24).

\section{Air quality hygiene}

Carbon dioxide and total ammonia levels in air of each group were detected (25) to deter-

Table 1: Definition of recorded behaviors mine the hygienic level inside all experimental groups.

\section{Statistical analysis}

All statistical procedures were performed using the SAS statistical system Package V9.2 (26). One-factorial analysis of variance (ANOVA) was performed. The analysis of data distribution suggested that all traits analyzed followed a normal distribution $(\mathrm{P}>0.05)$. Pearson correlations were performed to compute the relationship of the abnormal behavior and performance parameters.

\section{Results}

The results as shown in Table (2) revealed a significant differences in the most of the duck's behaviors, where the most of normal behaviors were the highest in plastic slatted and wood shaving, respectively. While, the abnormal behaviors (feather pecking and aggression) were significantly higher $(\mathrm{P}<0.05)$ in the non- bedding floor than other groups. Likewise, the growth parameters in Table (3) had notable differences among experimental groups with significant differences, where final body weight, body weight gain, growth rate were higher in plastic slatted floor than other groups. The hygienic conditions inside the non-bedding floor was the worst due to increase levels of ammonia and carbon dioxide, as shown in Table (4). The results in Table (5) showed that ducks reared in non-bedding floor bedding materials had the worst signs of health with significant increase in the level of plasma corticosterone hormone.

\begin{tabular}{ll}
\hline Observed behavior & Definition \\
\hline Eating & Number of eating bouts on the troughs \\
Drinking & Number of eating bouts on the drinkers \\
Foraging & $\begin{array}{l}\text { Number of pecking and scratching on ground, floor or other parts of } \\
\text { pen }\end{array}$ \\
Idling & Standing not engaged in any activity \\
Activity & Either walk or run \\
Laying & Laying or sitting on the floor \\
Feather preening & Clean and care about their plumage with their peak using short and re- \\
& peated action while standing or sitting \\
Feather pecking & Number of pecks at the feathered parts \\
Aggression & The ducks make hostile acts toward other birds \\
\hline
\end{tabular}


Table 2: Impact of different bedding material on behavior (mean $\pm \mathrm{SE}$ ) of ducks

\begin{tabular}{lcccc}
\hline Behavioral patterns & \multicolumn{4}{c}{ Different bedding material } \\
\cline { 2 - 5 } & wood shaving & Plastic slatted & Sand & No bedding \\
\hline Feeding frequency /hour & $10.1 \pm 0.54^{\mathrm{ab}}$ & $11.97 \pm 0.99^{\mathrm{a}}$ & $8.74 \pm 0.79^{\mathrm{b}}$ & $8.37 \pm 0.45^{\mathrm{b}}$ \\
Drinking frequency/hour & $14.4 \pm 4.80^{\mathrm{b}}$ & $29.31 \pm 6.37^{\mathrm{a}}$ & $9 \pm 1.58^{\mathrm{c}}$ & $5.41 \pm .98^{\mathrm{c}}$ \\
Foraging frequency/hour & $11.48 \pm 0.35^{\mathrm{a}}$ & $2.45 \pm 0.75^{\mathrm{c}}$ & $4.80 \pm 0.97^{\mathrm{b}}$ & $1.54 \pm 0.75^{\mathrm{c}}$ \\
Idling frequency/hour & $20.54 \pm 0.71^{\mathrm{a}}$ & $23.22 \pm 1.57^{\mathrm{a}}$ & $20.45 \pm 0.81^{\mathrm{a}}$ & $17 \pm 1.27^{\mathrm{b}}$ \\
laying frequency/hour & $7.62 \pm 2.39$ & $8.60 \pm 2.48$ & $6.97 \pm 1.18$ & $6.42 \pm 2.18$ \\
Activity frequency/hour & $23.37 \pm 1.80$ & $19.71 \pm 1.81$ & $23.02 \pm 1.79$ & $20.62 \pm 1.28$ \\
Feather preening frequency/hour & $11.87 \pm 2.25^{\mathrm{a}}$ & $12.20 \pm 1.16^{\mathrm{a}}$ & $10.62 \pm 0.96^{\mathrm{ab}}$ & $8.17 \pm 0.61^{\mathrm{b}}$ \\
Feather pecking frequency/hour & $49 \pm 13.58^{\mathrm{b}}$ & $21.03 \pm 2.44^{\mathrm{c}}$ & $56.41 \pm 19.8^{\mathrm{b}}$ & $74.40 \pm 14.82^{\mathrm{a}}$ \\
Aggression frequency/hour & $2.60 \pm 1.14^{\mathrm{b}}$ & $1.98 \pm 0.91^{\mathrm{b}}$ & $3.68 \pm 1.73^{\mathrm{ab}}$ & $5.51 \pm 2.04^{\mathrm{a}}$ \\
\hline
\end{tabular}

${ }^{a b c}$ Means in the same row with different superscripts are significantly different at $(\mathrm{P}<0.05)$

Table 3: The means $( \pm \mathrm{SE})$ of growth parameters in ducks reared under different bedding materials

\begin{tabular}{|c|c|c|c|c|}
\hline \multirow{2}{*}{ Growth parameters } & \multicolumn{4}{|c|}{ Different bedding material } \\
\hline & wood shaving & Plastic slatted & Sand & No bedding \\
\hline Initial body weight $(\mathrm{g})$ & $449.62 \pm 18.71$ & $435.88 \pm 15.91$ & $438.12 \pm 20.85$ & $438.88 \pm 14.05$ \\
\hline Final body weight & $3175.4 \pm 74.89^{b}$ & $3260.6 \pm 65.97^{\mathrm{a}}$ & $3044.3 \pm 71.17^{\mathrm{b}}$ & $2785.5 \pm 76.03^{c}$ \\
\hline Total body weight gain (g) & $2725.75 \pm 62.944^{a b}$ & $2824.75 \pm 57.87^{\mathrm{a}}$ & $2606.18 \pm 61.91^{b}$ & $2346.62 \pm 67.12^{c}$ \\
\hline Weekly body weight gain (g/bird/week) & $340.72 \pm 7.87$ ab & $353.09 \pm 7.23^{\mathrm{a}}$ & $325.77 \pm 7.74^{\mathrm{b}}$ & $293.33 \pm 8.39^{c}$ \\
\hline Feed intake (g/bird/week) & $968.75 \pm 78.12$ & $964.84 \pm 73.86$ & $955.5 \pm 71.12$ & $861.72 \pm 68.05$ \\
\hline Relative growth rate & $1.503 \pm 0.01^{\mathrm{a}}$ & $1.529 \pm 0.01^{\mathrm{a}}$ & $1.497 \pm 0.02^{\mathrm{a}}$ & $1.455 \pm 0.01^{\mathrm{b}}$ \\
\hline Feed conversion rate & $2.84 \pm 0.82$ & $2.73 \pm 0.83$ & $2.93 \pm 0.69$ & $2.94 \pm 1.63$ \\
\hline
\end{tabular}

Table 4: Levels of ammonia and carbon dioxide in air of different bedding materials groups

\begin{tabular}{lcccc}
\hline \multirow{2}{*}{ Environmental indicators } & \multicolumn{4}{c}{ Different bedding material } \\
\cline { 2 - 5 } & wood shaving & Plastic slatted & Sand & No bedding \\
\hline Total ammonia $\left(\mathrm{Cm}^{3}\right)$ & $7.76 \pm .43^{\mathrm{b}}$ & $10 \pm 1.15^{\mathrm{ab}}$ & $8.40 \pm .23^{\mathrm{b}}$ & $12 \pm 1.15^{\mathrm{a}}$ \\
Carbon dioxide $\left(\mathrm{Cm}^{3}\right)$ & $0.05 \pm .005^{\mathrm{d}}$ & $0.13 \pm .005^{\mathrm{b}}$ & $0.10 \pm .011^{\mathrm{c}}$ & $0.97 \pm .005^{\mathrm{a}}$ \\
\hline
\end{tabular}

${ }^{\text {abcd }}$ Means in the same row with different superscripts are significantly different at $(\mathrm{P}<0.05)$

Table 5: The level of corticosterone hormone $(\mu \mathrm{g} / \mathrm{dl})$ and mean rank of physical condition of duck under different bedding material

\begin{tabular}{lcccc}
\hline & \multicolumn{4}{c}{ Different bedding material } \\
\cline { 2 - 5 } & wood shaving & Plastic slatted & Sand & No bedding \\
\hline Eye & 1.25 & 1.25 & 1.25 & 1.66 \\
Nostril & 1.16 & 1.16 & 1.33 & 1.66 \\
Feather cleanliness & 1.04 & 0.87 & 1.29 & 1.91 \\
Feather quality & 1.08 & 1.08 & 1.25 & 1.83 \\
Foot pad & 1.21 & 1.21 & 1.45 & 1.54 \\
Gait & 1.21 & 1.21 & 1.21 & 1.70 \\
Corticosterone level $(\mu \mathrm{g} / \mathrm{dl})$ & $8.475 \pm 1.90^{\mathrm{bc}}$ & $4.82 \pm .58^{\mathrm{c}}$ & $13.17 \pm .2 .52^{\mathrm{ab}}$ & $14.55 \pm 1.16^{\mathrm{a}}$ \\
\hline
\end{tabular}

${ }^{\text {ab }}$ Means in the same row with different superscripts are significantly different at $(\mathrm{P}<0.05)$

\section{Discussion}

The concerning on how to manage duck's dropping under the intensive system, leading to the discovery several absorbents that were generally referred to bedding material (27). Behavioral study is considered the chief indicator to assess poultry welfare and poultry's response to the surrounding environment (17). In this study, there were several changes in duck's behaviors due to different bedding materials, as mentioned before in previous studies $(17,28$ 31). The bedding materials had significant effects on inestive behavior including eating, 
drinking and foraging, where the frequencies of eating and drinking behaviors were significantly higher in plastic slatted in comparing to other bedding materials. While foraging bouts were the highest significance in the bedding from sawdust material. These results agreed with Mohammed et al. (17), who found significant correlation between ingestive behavior and different bedding materials. While, the present study did not agree with Karousa et al. (31), who cited that litter types had no significant effect on feeding and drinking behaviors. As mentioned before in Table (2), the frequencies of ingestive behavior (eating, drinking and foraging) were the lowest significantly in no bedding materials, which confirm the importance of bedding materials to improve the ingstive behavior. The observed differences in ingestive behavior may be due to the properties of the bedding materials affected the quality of the ration and water (30).Furthermore, Toghyani et al., (32) mentioned that there were significant difference in ingestive behavior among different bedding materials. In this study, the laying frequency was the highest in plastic slatted and the lowest in non- bedding floor, but the difference did not reach the significance. This result may be attributed to the absence of comfortable media for the resting in no bedding group. These results agree with Anisuzzaman and Chowdhury (33) and disagreed with Stub and Vestergaard (34). The ducks reared in on nonbedding material was standing less significantly without any activities in comparison to other groups. This result was agreed with Mohammed et al., (17), while was disagreed with Toghyani et al., (32), who found that standing behavior was slatted but the differences did not reach the significance. Those changes in idling and laying behaviors, as comfortable behavior (5) may be due to the variations in cleanliness, odor and other characters of different litters (35). The bouts of activity (walking and running) were higher in sawdust and sand bedding than plastic slatted and non-bedding material which may be attributed to the changes in particle size of the litter (17). The difference in duck's activity in the present study was supported by Oliveira and Carvalho (36), who cited that the locomotion of birds was affected by different type of litter. The activity in plastic slatted was the lowest which may be due to the negative correlation between activity and the rate of food consumption (37). Regarding to feather preening, the ducks reared under plastic slatted floor and sawdust were more performance of feather preening with significant difference in comparing to other groups. This result may be due to the ducks more comfort on these floors. This result was agreed with Mohammed et al. (17), and disagreed with Waitt et al. (38) and Rice et al. (39), who found that the floor types hadno significance difference on preening behaviour of ducks. Sameh et al., (40) did not record any significant differences in preening behavior among different litter materials. Moreover, the abnormal behaviors representing in feather pecking and aggressive were significantly affected by the bedding, where it was the highest in non-bedding material and the lowest in plastic slatted floor. These results agreed with Mohammed et al. (17) and disagreed with Sameh et al. (40). Likewise, the bedding materials had significant effects on the most parameters of growth performance, where the plastic slatted was the highest and non-bedding group was the lowest. The improvement in growth performance in a plastic slatted litter may be attributed to the increase of all maintenance behaviors in this litter. The ducks reared in plastic slatted group revealed a significant increase in final body weight, total body weight gain, weekly body weight gain and growth rate by comparing to other experimental groups. These results were comparable to other studies, who mention that litter materials had a significant effect in growth parameters $(29,32,41)$. While, other researchers did not find a significant effect of bedding materials on growth performance (17). The feed consumption and feed conversion ratio did not reveal significant differences among the experimental group. Likewise, Davis et al., (42) and Mendes at el., (43) stated that different litters did not influence growth performance. While, other previous studies mention that bedding materials has a significant effect on feed consumption (44) and 
feed conversion ratio (45). The date as mentioned before in Table (4) revealed the hygienic conditions in the study, where the levels of ammonia and carbon dioxide were significantly higher in non-bedding litter in compare to others. These results may attributed to accumulation of fecal matter and increase the humidity in non-bedding litter (46). These results go hand by hand with results obtained by Tasistro et al. (47), who stated that there was a significant interaction between bedding materials and level of ammonia. Also, Almeida et al. (28) found that the use of perforated plastic flooring can improve the air quality (less $\mathrm{CO} 2$ and $\mathrm{NH} 3$ concentration) and bird cleanliness. Nevertheless, Fraley et al. (48) mentioned that there were no differences for any of the environmental data between flooring systems. Lien et al., (49) reported that the litter absorbs moisture, reduces ammonia production and finally may affect the total body weight gain. The signs of soundness in eye, nostril, feather, feet and gait were better in presence of bedding materials, especially in plastic slatted and sawdust, respectively. While the non- bedding litter was the worst in the previous signs. These results may attributed to ability of bedding materials to absorb moisture and may reflect the good managerial conditions (49). These results were comparable to Buhr et al. (50); Waitt et al. (38); Fraley et al. (48); Karcher et al. (22). Garcia et al. (30) cited that litter material had no effect on the physical condition of birds.

The level of plasma corticosterone was the highest significance in the non-bedding group, while the ducks reared in plastic slatted group revealed the lowest level of plasma cortisol. This result may be due to the ducks in plastic slatted floor had good signs of soundness. This result disagreed with that obtained by Asaniyan et al (27) and Sameh and El-Khloya (51), who noted that litter depth and litter type had no significant influence on hematological values and welfare indices.

\section{Conclusion}

In the present study, there were several changes in duck's behaviors due to different bedding materials, where the most of maintenance behaviors were the highest significantly in plastic slatted litter and the lowest in the nonbedding litter. Furthermore, growth parameters were the better in plastic slatted and sawdust floor, respectively, while the lowest growth parameters were in non-bedding floor. The hygienic conditions inside the non-bedding floor was the worst due to increased levels of ammonia and carbon dioxide. The ducks reared under non-bedding floor revealed the worst signs of soundness, while it was the best in plastic slatted floor. The plasma corticosterone is a useful indicator for acute and environmental stress, which was the highest in non-bedding litter. This study confirms importance of bedding materials in rearing of ducks, especially under plastic slatted floor.

\section{Conflict of interests}

None of the authors have any conflict of interest of declare.

\section{Acknowledgments}

We thank the staff at the Department of Veterinary Public Health, Faculty of Veterinary Medicine, Zagazig University, Egypt for providing materials used in this study. Also, we would like to thank the anonymous referees for their helpful comments on the manuscript.

\section{References}

1. Abdel GaiedS, BakriH. An economic evaluation for the impacts of spreading of bird flu on poultry sector in Egypt. World Agricultural Science 2009; 5(3): 264-9.

2. Taha A, Abd El-Ghany F, Sharaf M. Strain and sex effects on productive and slaughter performance of developed local Egyptian and Canadian chicken strains. Egyptian Poultry Science 2010; 30: 1059-72.

3. Witak B. Tissue composition of carcass, meat quality and fatty acid content of ducks of a commercial breeding line at different age. Archives Animal Breeding 2008; 51(3): 266-75.

4. Mohammed HH, Shereen EA, Enas N. Impact of different light color in behavior, welfare parameters and growth performance of Fayoumi broiler chickens strain. Hellenic Journal of Veterinary Association 2018; 69(2): 951-8. 
5. Mohammed HH, Badawi ME, Walaa MA, Ali MA, Abd El-Aziz RM. The influence of chromium sources on growth performance, economic efficiency, some maintenance behaviour, blood metabolites and carcass traits in broiler chickens. Global Veterinaria 2014; 12: 599-605.

6. Mohammed HH, Grashorn M, Bessei W. The effects of lighting conditions on the behaviour of laying hens. European Poultry Science 2010; 74: 197-202.

7. Aviagen A. guide to managing broilers in open-sided housing, available at: AVIAEnvMgtOpenSidedHseBroiler-EN-2016.

8. Al Homidan A, Robertson J. Effect of litter type and stocking density on ammonia, dust concentrations and broiler performance. British Poultry Science 2003; 44: S7-S8.

9. Seidavi A, Taherparvar G, Leila A, ParesCasanova P. Effect of different litters supplemented with chemical agents on broiler carcass components. Journal of Fisheries and Livestock Production 2015; 3: 1-4.

10. Benabdeljelil K, Ayachi A. Evaluation of alternative litter materials for poultry. Applied Animal Research 1996; 5(3): 203-9.

11. De Avila V, De Oliveira U, De Figueiredo E, Costa A, Abreu M, Rosa P. Alternative material to replace wood shavings as broiler litter. Revista Brasileira Zootec 2008; 37: 273-7.

12. Shields S, Garner J, Mench J. Effect of sand and wood-shavings bedding on the behavior of broiler chickens. Poultry Science 2005; 84(12): 1816-24.

13. Savory C. Broiler welfare: Problems and prospect. Special edition of OECDWorksh"Growth and quality in broiler production" 1995.

14. Bilgili S, Montenegro G, Hess J, Eckman M. Sand as litter for rearing broiler chickens. Journal of Applied Poultry Research 1999; 8(3): 345-51.

15. Arnould C, Bizeray D, Faure J, Leterrier C. Effects of the addition of sand and string to pens on use of space, activity, tarsal angulations and bone composition in broiler chickens. Animal Welfare 2004; 13(1): 87-4.

16. Shields S, Garner J, Mench J. Dust bathing by broiler chickens: a comparison of preference for four different substrates. Applied Animal Behavior Science 2004; 87: 69-82.

17. Mohammed HH, Enas S, Shereen EA. Impact of different litter materials on behaviour, growth performance, feet health and plumage score of Japanese quail (Coturnix japonica). European Poultry Science 2017; 81: 719-27.
18. Sari M, Önk K, Isik S, Tilki M, Tufan T. Effects of housing system, slaughter age, and sex on slaughter and carcass traits of native Turkish ducks. Turkish Journal of Veterinary and Animal Sciences 2013; 37(6): 694-700.

19. AOAC. Official Methods of Analysis. Association official analytical chemists, Gaithersburg, USA 2002.

20. Amado M, Xavier D, Boere V, Torres-Pereira C, McManus C, Bernal F. Behaviour of captive ostrich chicks from 10 days to 5 months of age. Revista Brasileira Zootec 2011; 40 (7): 1613-8.

21. Shimmur T, Hirahara S, Eguchi Y, Uetake K, Tanaka T. Behaviour and Physiology, performance and physical condition of layers in conventional and large furnished cages in a hot environment. Animal Science 2007; 78: 314-22.

22. Karcher D, Makagon M, Fraley G, Fraley S, Lilburn M. Influence of raised plastic floors compared with pine shaving litter on environment and Pekin duck condition. Poultry Science 2013; 92(3): 583-90.

23. Mohammed HH, Mohamed I, Al Sadik S. Effect of different light intensities on performance, welfare and behaviour of turkey poults. Journal of Advance Veterinary and Animal Research 2016; 3(1): 18-23.

24. Abdel-Rahman M. Study on the effect of stocking density and floor space allowance on behaviour, health and productivity of turkey broilers. Journal of Assiut Veterinary Medicine 2005; 51: 113.

25. Houping H, Shih-Ger C. Method of regenerate ammonia for the capture of carbon dioxide. Energy Fuels 2002; 16(4): 904-10.

26. SAS. SAS statistical system Package-Jmp 8 User's Guide.2nd Cary, NC, SAS Institute Inc. USA. ISBN 2009.

27. Asaniyan EK, Agbede JO, Laseinde EA. Impact assessment of different litter depths on performance of broiler chickens raised on sand and wood shaving litters. World Journal of Zoology 2007; 2(2): $67-72$.

28. Almeida EA, Sant'Anna AC, Crowe TG, Macari M, Furlan RL. Poultry rearing on perforated plastic floors and the effect on air quality, growth performance, and carcass injuries-Experiment 2: Heat stress situation. Poultry Science 2010; 12(3): 189-195.

29. El-Deek AA, Al-Harthi MA, Khalifah MM, Elbanoby MM, Alharby T. Impact of newspaper as bedding material in arid land on broiler performance. Egyptian Poultry Science 2011; 31: 715-25. 
30. Garcia RG, Almeida Paz IL, Caldara FR, Nääs IA, Bueno LF, Freitas LW, Sim S. Litter materials and the incidence of carcass lesions in broilers chickens. Revista Brasileira de Ciência Avícola 2012; 14(1): 27-32.

31. Karousa MM, Meneeh IS, Ahmed SA, Ahmed EA, Youseif HA. Effect of litter materials on broiler behaviour and performance. Benha Veterinary Medical Journal 2012, 23(1): 142-9.

32. Toghyani M, Gheisari A, Modaresi M, Tabeidian SA. Effect of different litter material on performance and behavior of broiler chickens. Applied Animal Behaviour Science 2010; 122(1): 4852.

33. Anisuzzaman M, Chowdhury SD. Use of four types of litter for rearing broilers. British Poultry Science 1996; 37(3): 541-5.

34. Stub C, Vestergaard KS. Influence of zinc bacitracin, light regimen and dust bathing on the health and welfare of broiler chickens. British Poultry Science 2001; 42(5): 564-8.

35. Villagrá A, Olivas I, Althaus RL, Gómez EA, Lainez M, Torres A. Behavior of broiler chickens in four different substrates: a choice test. Revista Brasileira de Ciência Avícola 2014; 16(1): 6775.

36. Oliveira MC, Carvalho ID. Rendimento e lesões em carcaça de frangos de cortecriadosem diferentes camas e densidades populacionais. CiencAgrotec 2002; 26: 1076-81.

37. Hocking PM, Hughes BO, Keer S. Comparison of food intake, rate of consumption, pecking activity and behavior in layer and broiler breeder males. British Poultry Science 1997; 38: 237-40.

38. Waitt C, Jones T, Dawkins MS. Behaviour, synchrony and welfare of Pekin ducks in relation to water use. Applied Animal Behaviour Science 2009; 121(3): 184-9.

39. Rice M, Meelker A, Fraley SM, Fraley GS. Characterization of Pekin duck drinking and preening behaviors and comparison when housed on raised plastic versus pine litter flooring. Journal of Applied Poultry Research 2014; 23(4): 735-41.

40. Sameh GA, Hamada DH, Mohamed AH, Khaled MG. Behaviour, welfare and performance of broiler chicks reared on different litter materials. Assiut Veterinary Medicine 2013; 59: 9-18.

41. Senaratna D, Atapattu NS, Belpagodagamage DU. Saw dust and refuse tea as alternative lit- ter materials for broilers. Tropical Agricultural Research 2007; 19: 283-9.

42. Davis JD, Purswell JL, Columbus EP, Kiess AS. Evaluation of chopped switch grass as a litter material. International Journal of Poultry Science 2010; 9(1): 39-42.

43. Mendes AS, Paixão SJ, Restelatto R, Reffatti R, Possenti JC, De Moura DJ, De Carvalho TR. Effects of initial body weight and litter material on broiler production. Revista Brasileira de Ciência Avícola 2011; 13(3): 165-70.

44. Abreu VM, Abreu PG, Coldebella A, Jaenisch FR, Silva VS. Evaluation of litter material and ventilation systems in poultry production: I. overall performance. Revista Brasileira Zootec 2011; 40: 1364-71.

45. Asaniyan EK, Agbede JO, Laseinde EA. Comparative influence of sand and wood shavings litter replacement frequency on the performance of broiler chickens. Journal of Animal and Veterinary Advances 2006; 5(12): 1080-7.

46. Jones TA, Dawkins MS. Environment and management factors affecting Pekin duck production and welfare on commercial farms in the UK. British Poultry Science 2010; 51(1): 12-21.

47. Tasistro AS, Ritz CW, Kissel DE. Ammonia emissions from broiler litter: response to bedding materials and acidifiers. British Poultry Science 2007; 48(4): 399-405.

48. Fraley SM, Fraley GS, Karcher DM, Makagon MM, Lilburn MS. Influence of plastic slatted floors compared with pine shaving litter on Pekin Duck condition during the summer months. Poultry Science 2013; 92(7): 1706-11.

49. Lien RJ, Hess JP, Conner DE, Wood CW, Shelby RA. Peanut hulls as a litter source for broiler breeder replacement pullets. Poultry Science 1998; 77: 41-6.

50. Buhr RJ, Cason JA, Dickens JA, Hinton JA, Ingram KD. Influence of flooring type during transport and holding on bacteria recovery from broiler carcass rinses before and after defeathering. Poultry Science 2000, 79(3): 436-41.

51. Sameh GA, El-Khloya SZ. Do alternative litter Materials Affect performance, Welfare and Immune Response of Broiler Chicks?. Alexandria Journal for Veterinary Sciences 2017; 52(1): $133-41$. 